\title{
Role of gonadotrophins in regulating numbers of Leydig and Sertoli cells during fetal and postnatal development in mice
}

\author{
P. J. Baker and P. J. O'Shaughnessy* \\ Division of Veterinary Physiology and Pharmacology, Department of Veterinary Preclinical \\ Studies, University of Glasgow Veterinary School, Bearsden Rd, Glasgow G61 1QH, UK
}

The role of the gonadotrophins in regulating numbers of Leydig and Sertoli cells during fetal and postnatal development was examined using normal mice and hypogonadal (hpg) mice, which lack circulating gonadotrophins. The disector method was used to determine the number of cells from day 16 of gestation until adulthood. The numbers of Leydig cells did not change significantly between day 16 of gestation and day 5 after parturition in normal mice and were not significantly different from numbers in hpg mice at any age up to day 5 after parturition. There was a 16-fold increase in the number of Leydig cells in normal mice between day 5 and day 20 after parturition, followed by a further doubling of number of cells between day 20 and adulthood. The number of Leydig cells in hpg testes did not change between day 5 and day 20 after parturition but doubled between day 20 and adulthood so that the number of cells was about $10 \%$ of normal values from day 20 onwards. Leydig cell volume was constant in normal animals from birth up to day 20 and then showed a 2.5 -fold increase in adult animals. Leydig cell volume was normal in hpg testes at birth but decreased thereafter and was about $20 \%$ of normal volume in adult mice. The number of Sertoli cells increased continuously from day 16 of gestation to day 20 after gestation in normal mice and then remained static until adulthood. The number of Sertoli cells in hpg testes was normal throughout fetal life but was reduced by about $30 \%$ on day 1 (day of parturition). Thereafter, Sertoli cells proliferated at a slower rate but over a longer period in the hpg testis so that on day 20 after parturition the number of Sertoli cells was about $50 \%$ of normal values, whereas in adult mice the number was $65 \%$ of normal. The number of gonocytes did not change between day 16 of gestation and day 1 and did not differ between normal and hpg testes. The number of gonocytes increased nine-fold in normal testes but only three-fold in hpg testes between day 1 and day 5 after parturition. Gonocytes differentiated into spermatogonia in both normal and hpg testes between day 5 and day 20 after parturition. These results show: (i) that fetal development of both Sertoli and Leydig cells is independent of gonadotrophins; (ii) that normal differentiation and proliferation of the adult Leydig cell population (starting about day 10 after parturition) is dependent on the presence of gonadotrophins; and (iii) that the number of Sertoli cells after birth is regulated by gonadotrophins, although proliferation will continue, at a lower rate and for longer, in the absence of gonadotrophins.

\section{Introduction}

The first critical steps in testicular development from the indifferent gonad and subsequent masculinization of the fetus are differentiation of the Sertoli cells and Leydig cells (Byskov, 1986; Magre and Jost, 1991). Resultant formation of the male reproductive tract and degeneration of the female tract depends on normal development and function of these cell populations (Jost et al., 1973). Currently, we lack a full understanding of the factors that normally regulate the numbers of Sertoli and Leydig cells during fetal and neonatal life, although it is clear that this is a critical period for subsequent development of normal reproductive function (Orth et al., 1988; Lejeune et al., 1998).

Gonadotrophins regulate the activity of pubertal and

*Correspondence

Email: P.J.OShaughnessy@vet.gla.ac.uk post-pubertal populations of Sertoli cells and Leydig cells (Griswold, 1993; Lejeune et al., 1998), although the role of these hormones in determining the number of testicular cells during the fetal and neonatal periods remains unclear. Evidence from earlier studies in rats and sheep indicates that proliferation of Sertoli cells is at least partially gonadotrophin-dependent during fetal life (Orth, 1984; Thomas et al., 1994), although the stage at which dependency begins is not known. In contrast, there have been no studies to determine whether Leydig cell proliferation and differentiation are gonadotrophindependent during the fetal and neonatal period, although O'Shaughnessy et al. (1998) showed that Leydig cell function is independent of pituitary control during this time.

The aim of the present study was to measure Leydig cell, Sertoli cell and gonocyte numbers during fetal and postnatal development in normal mice and in hypogonadal ( $h p g$ ) mice, which lack $\mathrm{GnRH}$, and, therefore, endogenous 
circulating gonadotrophins (Cattanach et al., 1977). These data demonstrate the stages of development at which proliferation of each cell type becomes gonadotrophindependent and the role of the gonadotrophins in determining the number of cells at puberty.

\section{Materials and Methods}

\section{Animals}

Normal and hpg mice were bred at the University of Glasgow Veterinary School from stock derived originally from the Oxford breeding colony. Animals were maintained as required under United Kingdom Home Office regulations as applied to the use of experimental animals. For timing of fetal development, males were caged overnight with females and the morning was designated as day 0.5 of gestation. For studies on post-natal animals the day of birth was designated as day 1 . Adult animals were aged between 70 days and 120 days. Normal and hpg mice were distinguished before puberty by PCR as described by Lang (1995).

\section{Fixation and processing}

For cell counting using the physical disector method (see below) testes were fixed by immersion in $2.5 \%(\mathrm{w} / \mathrm{v})$ glutaraldehyde, $2 \%(\mathrm{w} / \mathrm{v})$ paraformaldehyde and $0.1 \%(\mathrm{w} / \mathrm{v})$ picric acid in 0.1 mol cacodylate buffer $\mathrm{I}^{-1}(\mathrm{pH} 7.4)$. After osmication and dehydration, each testis was embedded in Technovit 7100 (Kulzer and Co, GmbH, Wehrheim) and cut into sections ( $2 \mu \mathrm{m}$ thickness). Every tenth or twentieth pair of sections was mounted and stained with toluidine blue in $1 \%(\mathrm{w} / \mathrm{v})$ borax. For cell counting using an optical disector (see below) testes were fixed in Bouin's fluid overnight, placed in $70 \%(\mathrm{v} / \mathrm{v})$ alcohol and embedded in Technovit 7100 resin. The testes were cut into sections $(20 \mu \mathrm{m}$ thickness) and stained with Harris' haematoxylin.

\section{Sterology}

Two methods of cell counting were used. Most testes were analysed using the physical disector method, but towards the end of the study equipment and software were obtained to allow the optical disector to be used. The two methods provide comparable data (Wreford, 1995 and the present study) but the optical disector is considerably faster. Total testis volume was estimated for both methods using the Cavalieri principle (Mayhew, 1992) and the slides used to estimate the number of cells were also used to estimate testis volume to avoid any requirement for correction factors due to tissue shrinkage. A computer running AutoCADlt97 software (Autodesk Inc, San Rafael, CA) and a digitizing tablet were used to estimate the surface area of selected sections (every tenth or twentieth section). The total surface area of these selected sections is designated $S A$. The thickness of each section is known $(h)$, as is the distance between the sections $(d)$, and so total testis volume
( $T_{\mathrm{v}}$ ) can be calculated by $T_{\mathrm{v}}=S A \times h \times d$. For the physical disector the method used was based on previous descriptions by Sterio (1984) and Gundersen (1986). A Leitz Laborlux S microscope with an attached drawing tube was used to view randomly selected areas of testis with a $\times 100$ oil immersion objective. The drawing tube allowed the outline of the nuclei present to be drawn onto a disector counting frame enclosing an area of $4500 \mu \mathrm{m}^{2}$. The same area was located in the adjacent section and the nuclei were drawn onto an acetate sheet. Nuclei present in one image but not in both were then counted. A running mean of the number of nuclei present in each pair of drawings was calculated and cell counting was continued until the standard deviation coefficient of the means of the last 50 measurements was $<5 \%$. The optical disector technique (Wreford, 1995) was used to count the number of Leydig and Sertoli cells in the testes of normal and hpg adult mice. The numerical density of each cell type was estimated using an Olympus BX50 microscope fitted with a motorized stage (Prior Scientific Instruments, Cambridge) and Stereologer software (Systems Planning Analysis, Alexandria, VA).

The volume density of Leydig cells was determined by the point-counting method using the Stereologer program. Testis sections were cut ( $2 \mu \mathrm{m}$ thickness) and the software firstly selected the areas of tissue to be counted and then superimposed a 121 point grid over a video image taken with a $\times 100$ objective lens. At least 100 grids were counted for each testis measured. The mean Leydig cell volume was determined by multiplying the volume density by the total testis volume and dividing by the total number of Leydig cells.

In all studies, gonocytes, Sertoli cells and Leydig cells were identified as described by Hardy et al. (1989), Vergouwen et al. (1991) and Duckett et al. (1997).

\section{Statistical analysis}

Results were analysed by two-way ANOVA followed by comparison of individual means using $t$ tests.

\section{Results}

\section{Testis volume}

Changes in testis volume during development in normal and hpg mice are shown (Fig. 1). There was no difference in testis size between the two groups until birth. After birth, testis volume in normal mice continued to increase rapidly, in contrast to the hpg mice, which showed a much slower growth rate. By adulthood the volume of the $h p g$ testis was about $1.5 \%$ of that of normal mice.

\section{Leydig cells}

Fetal Leydig cells were identified by their rounded nuclei and distinct, darkly stained cytoplasm, which sometimes contained lipid droplets (Fig. 2a-d). Up to day 1 (day of parturition) the cells appeared singly or in small groups and 


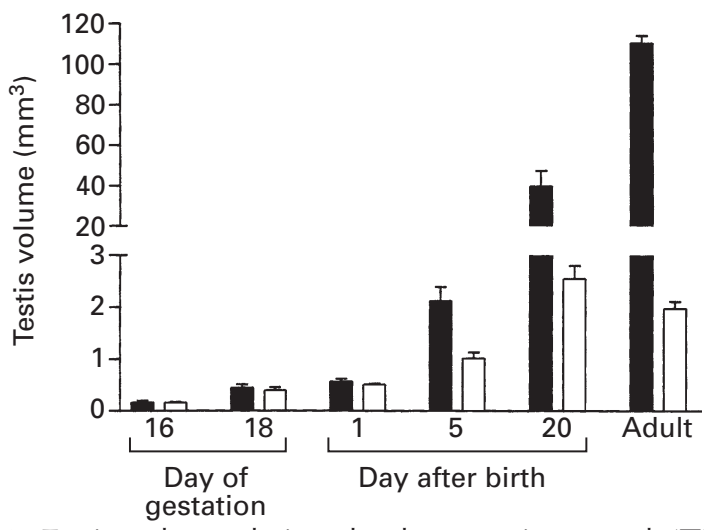

Fig. 1. Testis volume during development in normal (ם) and hypogonadal $(h p g)(\square)$ mice. Values are mean \pm SEM.

there were no clear differences in morphology between normal and $h p g$ mice. On day 5 after birth, larger clusters of Leydig cells began to appear in normal animals and on day 20 clusters of cells with a more variable nuclear morphology and less distinct cytoplasmic boundaries were observed (Fig. 2e,g). These cells frequently contained small lipid droplets (Fig. $2 \mathrm{~g}$ ) and had a similar morphology to cells in adult mice (not shown). In hpg testes the Leydig cells after day 5 were characterized by the presence of large lipid droplets as described by O'Shaughnessy and Sheffield (1990) (Fig. 2h,i). Leydig cells usually appeared singly in hpg testes after day 5 (Fig. 2h) except near the rete testis where clusters of Leydig cells were observed (Fig. 2i).

Leydig cell volume did not change in normal mice between birth and day 20 but then increased approximately 2.5 -fold to adulthood (Fig. 3). Leydig cell volume in hpg mice was normal at birth but decreased to about $50 \%$ of normal values by day 20 after parturition. There was no hypertrophy of Leydig cells in adult hpg mice and the volume of these cells was about $20 \%$ of normal volume in adult mice.

There was little or no change in the number of Leydig cells during late fetal or early neonatal life in normal mice (Fig. 4). However, between day 5 and day 20 after birth, the number of cells increased 16 -fold followed by a further doubling between day 20 and adulthood (Fig. 2). In hpg mice, the number of Leydig cells was not significantly different from that in normal mice throughout fetal life and up to day 5 after birth. After day 5, the number of Leydig cells increased slightly in hpg mice up to day 20 and then doubled between day 20 and adulthood so that on day 20 and in adult mice the number of Leydig cells in hpg mice was about $10 \%$ of normal values.

\section{Sertoli cells}

During fetal development the Sertoli cells were clearly identifiable within the developing tubules of normal and hpg mice. The nuclei were of variable sizes and shapes and were located towards the periphery of the tubules (Fig. 2a-d). In early neonatal life, the Sertoli cell nuclei tended to become more central and by day 20 after birth they had assumed an adult morphology in normal mice (Fig. 1e). There were no clear morphological differences between Sertoli cells from normal and hpg mice.

The number of Sertoli cells in normal mice increased rapidly throughout late fetal life and early post-natal life with a 6.5 -fold increase in number between day 16 of gestation and birth and a four-fold increase between birth and day 5 (Fig. 4). After day 5, the rate of proliferation decreased and there was a 1.9-fold increase in the number of Sertoli cells between day 5 and day 20, with no further increase thereafter. The number of Sertoli cells was normal in $h p g$ mice during fetal life up to day 18 of gestation but significantly lower at birth (Fig. 4). After birth, the number of Sertoli cells continued to increase in the hpg mice but at a slower rate than in normal mice, so that by day 5 and day 20 after birth the numbers of Sertoli cells in hpg mice were $51 \%$ and $48 \%$ of normal values, respectively (Fig. 4). However, proliferation of Sertoli cells in the hpg testes continued beyond day 20 after birth, so that by adulthood the number of Sertoli cells was about $65 \%$ of normal values (Fig. 4).

\section{Gonocytes}

The gonocytes in normal and hpg testes were clearly identifiable in the fetal testes with large round nuclei, often surrounded by a distinct cytoplasm, and situated within the lumen of the tubules. The gonocytes were clearly distinguishable from the nuclei of the Sertoli cells (Fig. 2). Some cells had migrated to the basement membrane of the tubules by day 5 after birth and by day 20 the gonocytes had differentiated into spermatogonia in both normal and hpg testes (Fig. 2e,f). Further differentiation and development along the spermatogenic pathway was significantly greater at day 20 in normal mice compared with hpg mice (Fig. $2 e, f)$.

Gonocyte numbers did not change between day 16 of gestation and birth in normal mice (Fig. 4). There was a nine-fold increase in the number of gonocytes in normal testes between day 1 and day 5 . In the $h p g$ mice, gonocyte numbers were not significantly different from normal values during fetal life. There was an increase in gonocyte numbers in $h p g$ mice between day 1 and day 5 after birth, but the rate of proliferation was lower than in normal mice and gonocyte numbers were reduced significantly on day 5 .

\section{Discussion}

Normal masculinization of the fetus and fertility in adult life depend on differentiation and development of Leydig cells and Sertoli cells during fetal and neonatal life. The results of the present study show that, during the fetal period, differentiation and proliferation of both Sertoli cells and Leydig cells are largely independent of endogenous gonadotrophins. After birth, normal development of the number of cells becomes gonadotrophin-dependent in both cell types 

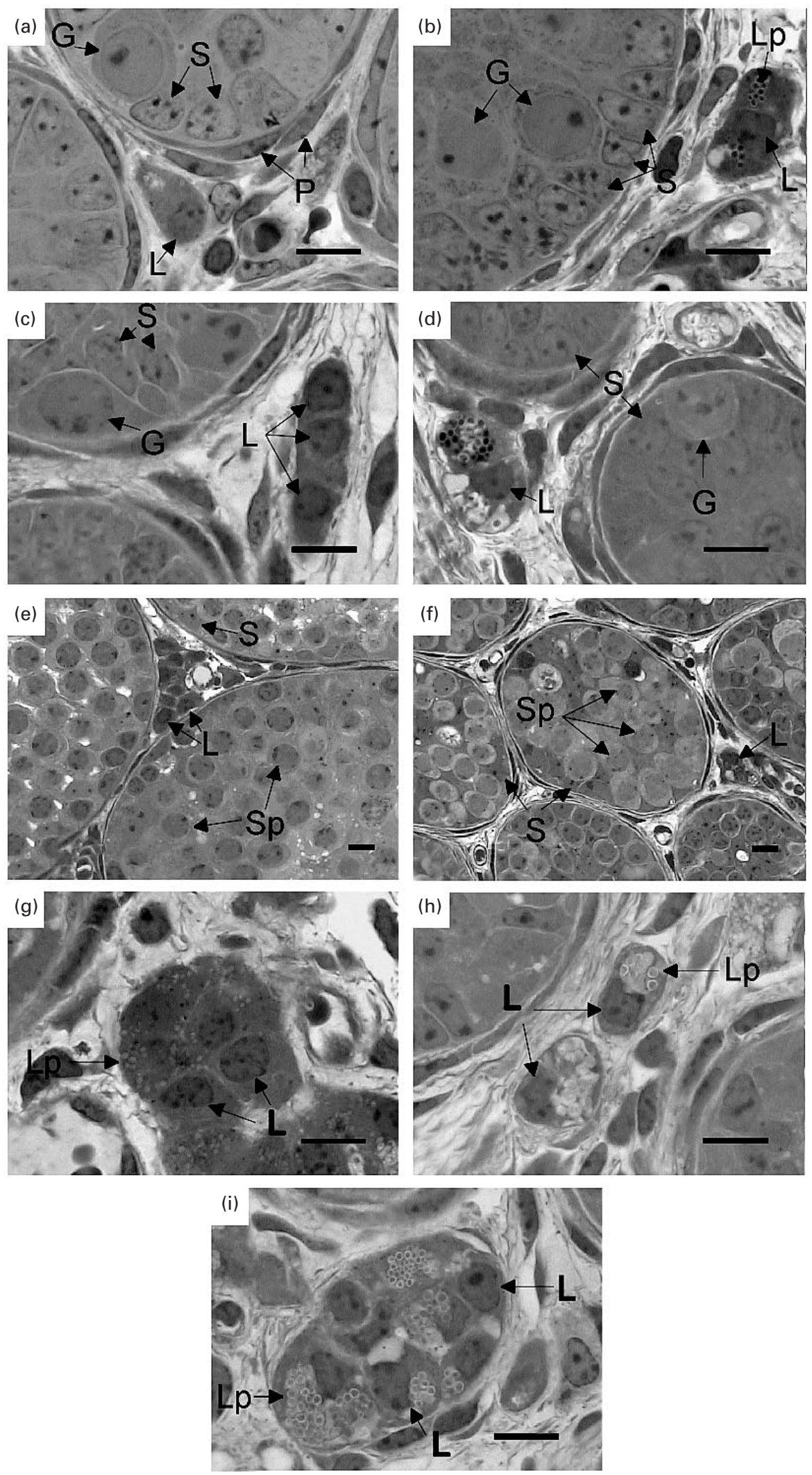

Fig. 2. Photomicrogaphs of testicular tissue from mice of different ages stained with toluidine blue. (a) Normal mouse on day 1 (day of birth); (b) hypogonadal (hpg) mouse on day 1 ; (c) normal mouse on day 5; (d) hpg mouse on day 5; (e) normal mouse on day 20; (f) hpg mouse on day 20; (g) normal mouse on day 20; (h) hpg mouse on day 20; and (i) hpg 


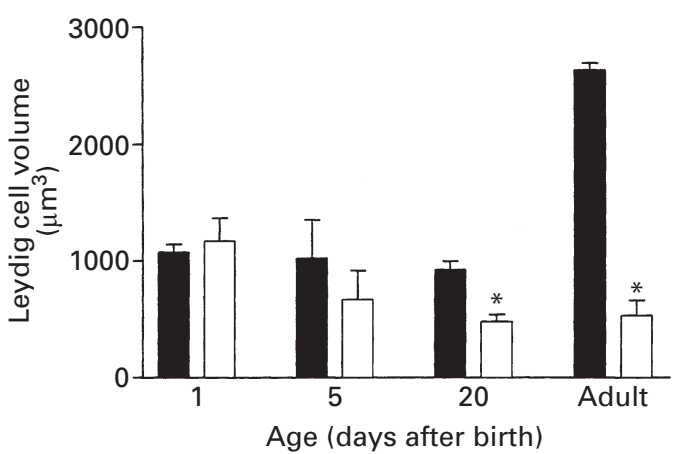

Fig. 3. Leydig cell volume during post-natal development in normal ( $\square$ ) and hypogonadal (hpg) ( $\square$ ) mice. Values are mean \pm SEM. *Indicates that there is a significant difference in the number of cells between normal and $h p g$ mice at that age $(P<0.05)$.

but by day 20 the effect of gonadotrophin withdrawal is considerably greater in Leydig cells than in Sertoli cells.

The number of Leydig cells in normal mice did not change significantly between day 16 of gestation and day 5 after birth, and then increased markedly to $6 \times 10^{5}$ cells per testis at day 20 after birth. Vergouwen et al. (1991, 1993) showed that labelling of Leydig cells by $\left[{ }^{3} \mathrm{H}\right]$ thymidine was very low through fetal life from day 14 of gestation, and that the number of Leydig cells remained constant after birth up to day 10 before increasing significantly to $5 \times 10^{5}$ cells per testis at day 18. Together, the results of the present study and Vergouwen et al. $(1991,1993)$ indicate that after initial differentiation and proliferation of fetal Leydig cells at about day 12 of gestation (Gondos, 1980) there is little further change in the size of the fetal Leydig cell population. In mice, as in other species, a separate adult population of Leydig cells arises before puberty with adult cells first detectable in the mouse about days 7-10 (Baker et al., 1999; Nef et al., 2000). Therefore, it is highly likely that the increase in the number of Leydig cells after day 10 is due to differentiation and proliferation of the adult population. The normal number of Leydig cells observed in fetal/neonatal hpg testes demonstrates that the number of fetal Leydig cells is not dependent on gonadotrophins. This finding is in agreement with studies in sheep in which fetal hypophysectomy did not alter the number of fetal Leydig cells (Hochereau-de Reviers et al., 1995). Currently, little is known about the factors that govern differentiation and early proliferation of fetal Leydig cell populations, although Sry may be involved in regulating proliferation of the preLeydig cell lineage (Schmahl et al., 2000). Lack of Wnt4 expression appears to be essential for fetal Leydig cell differentiation (Vainio et al., 1999). Animals lacking Desert hedgehog $(D h h)$ are feminized at birth, indicating a role for Dhh in fetal Leydig cell differentiation or function (Clark et al., 2000).
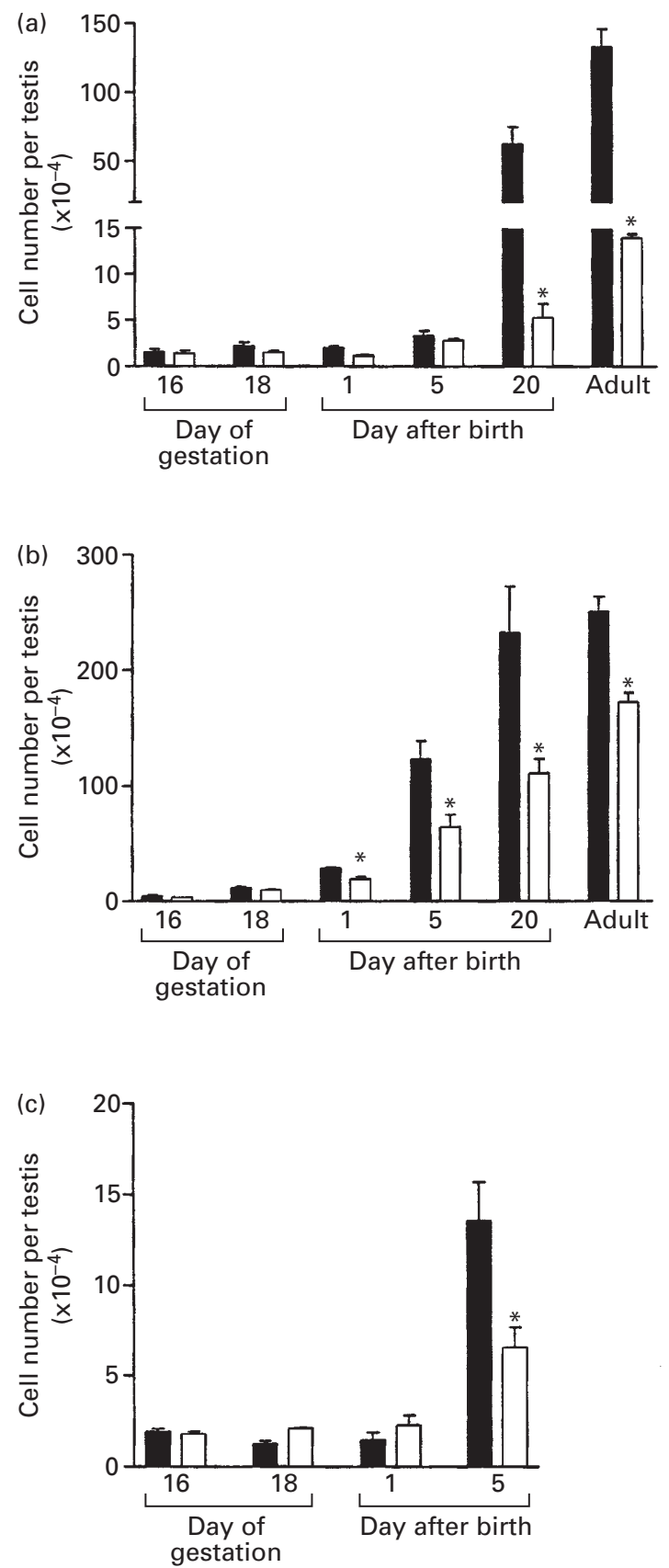

Fig. 4. Changes in numbers of (a) Leydig cells, (b) Sertoli cells and (c) gonocytes in the testes of normal ( $\square$ ) and hypogonadal (hpg) ( $\square$ ) mice during development. Values are mean $\pm \operatorname{SEM}(n=3-6$ mice). *Indicates that there is a significant difference in the number of cells between normal and $h p g$ mice at that age $(P<0.05)$.

Unlike the fetal Leydig cell population, failure of normal numbers of adult Leydig cells to develop after day 5 in hpg mice shows that the adult Leydig cell population is critically dependent on gonadotrophins for establishment of a normal population size at this time. This finding is 
consistent with recent studies on LH receptor knockout mice which indicate that the numbers of Leydig cells are reduced in adult animals (Lei et al., 2001; Zhang et al., 2001), although the cells were not counted in these studies and comparisons cannot be made with the results reported here. Dependence upon gonadotrophins for Leydig cell proliferation after day 5 correlates with what is known about control of fetal and adult Leydig cell function. During fetal development, testosterone concentrations and expression of steroidogenic enzymes are normal in the testes of hpg mice (O'Shaughnessy et al., 1998). However, after birth there is a rapid decrease in intratesticular testosterone concentrations in the testes of hpg mice so that by day 5 testosterone is largely undetectable and remains undetectable into adulthood (Scott et al., 1990; O'Shaughnessy et al., 1998). Thus, maintenance of fetal Leydig cell function becomes gonadotrophin-dependent shortly after birth but as there is little or no Leydig cell proliferation at this time in normal mice, no effect of gonadotrophin deficiency on the numbers of cells is observed.

A study by Ariyaratne et al. (2000) has indicated that initial functional differentiation of adult Leydig cell precursors in rats might be independent of LH. In mice, as in rats, this will occur between day 10 and day 20, a period during which there is little change in the number of Leydig cells in hpg testis. This finding indicates that $\mathrm{LH}$ is either required for proliferation of differentiated adult Leydig cells during this period or early functional differentiation of precursors to pre-Leydig cells may be LH-independent, whereas later development of these Leydig cells is $\mathrm{LH}$ dependent. Interestingly, in hpg mice there is an approximate doubling of the number of Leydig cells between day 20 and adulthood, about the same percentage increase as in normal mice. This late increase in the number of Leydig cells may be partly due to $\mathrm{LH}$-independent differentiation of Leydig cells in both normal and hpg mice or may be due to induction of Leydig cell proliferation by factors such as antiMullerian hormone and thyroxine (Behringer et al., 1994; Mendis-Handagama et al., 1998; Racine et al., 1998; Teerds et al., 1998). In addition, studies on Dhh-null mice have indicated that Dhh may be a crucial regulator of adult Leydig cell and precursor cell differentiation (Nef et al., 2000).

At birth, Leydig cell volumes were normal in the testes of hpg mice, which is a further indication that function in these cells is also normal at this time. Early adult Leydig cell volume in normal animals was the same as fetal Leydig cell volume but there was a marked hypertrophy of the cells after puberty. Leydig cell volume decreased in the hpg testes after birth and remained low in the adult mice, thereby indicating that adult hypertrophy in normal mice is gonadotrophin-dependent.

The numbers of Sertoli cells in normal mice increased throughout fetal and neonatal development up to day 20. This finding is in agreement with a number of earlier studies in various species which have shown that Sertoli cell proliferation occurs mainly during fetal and prepubertal life
(Steinberger and Steinberger, 1971; Curtis and Amann, 1981; Orth, 1982, 1984; Johnson et al., 1984; Kluin et al., 1984; Bortolussi et al., 1990; Vergouwen et al., 1991, 1993; Hochereau-de Reviers et al., 1995). The number of Sertoli cells determined in the present study at day 20 after birth and in adult mice (approximately $2.3 \times 10^{6}$ cells per testis) is in good agreement with the number reported by Vergouwen et al. (1993) after day 18 (approximately $1.8 \times$ $10^{6}$ cells per testis). A number of studies have shown that in rats a reduction of circulating gonadotrophin concentrations during the neonatal period leads to a reduction of about $45 \%$ in the number of Sertoli cells (van den Dungen et al., 1990; Atanassova et al., 1999; Sharpe et al., 1999, 2000). The results of the present study now extend this finding to show that, in mice, fetal development is largely gonadotrophin-independent and that a requirement for gonadotrophins is not established until late fetal life. This finding is consistent with earlier studies by Orth (1984) showing that late decapitation of rat fetuses or injection of $\mathrm{FSH}$ antiserum at day 18 of gestation reduced $\left[{ }^{3} \mathrm{H}\right]$ thymidine incorporation into Sertoli cells. After birth, the rate of proliferation of Sertoli cells in the testes of hpg mice was reduced significantly, which is consistent with data described above for neonatal rats and with studies showing that treatment of intact neonatal rats or neonatal hpg mice with FSH will increase the number of Sertoli cells (Meachem et al., 1996; Singh and Handelsman, 1996). Interestingly, proliferation continued in the hpg testes after day 20, which may indicate that gonadotrophins are required to stop Sertoli cell proliferation at the start of puberty.

The gonadotrophin-independent Sertoli cell proliferation during fetal life and the continued proliferation after birth in hpg mice, albeit at a lower rate, highlights the importance of other factors in regulating the number of Sertoli cells. Early proliferation of Sertoli cells, before sex cord formation, appears to be stimulated by Sry (Schmahl et al., 2000) and there is clear evidence that thyroxine acts to inhibit Sertoli cell proliferation in the neonatal period (van Haaster et al., 1992, 1993). Regulation of the fetal growth of the number of Sertoli cells remains unclear, although Fmr1, glial cell linederived neurotrophic factor and transforming growth factor $\alpha$, may all be involved (Slegtenhorst-Eegdeman et al., 1998; Hu et al., 1999; Levine et al., 2000; Petersen et al., 2000). The role of these and other factors in determining the final numbers of Sertoli cells in normal testes remains to be elucidated.

The testes of hpg mice have very low testosterone concentrations after birth $\left(\mathrm{O}^{\prime}\right.$ Shaughnessy and Sheffield, 1990; O'Shaughnessy et al., 1998) and the reduced Sertoli cell proliferation in the neonatal period may be due to lack of androgen stimulation rather than direct FSH stimulation. However, Singh and Handelsman (1996) have shown that neonatal treatment of $h p g$ mice with testosterone does not change subsequent numbers of Sertoli cells in the adult mice. As testosterone concentrations are normal in hpg testes in the fetal period (O'Shaughnessy et al., 1998) it 
is likely that the reduced number of Sertoli cells in neonatal hpg testes is due directly to lack of FSH.

Primordial germ cells divide mitotically in developing fetal mouse testes until about day 13.5 of gestation and then arrest until just after birth when they resume mitosis (McLaren, 1984). As the number of gonocytes present during fetal life is determined by day 13.5 it is to be expected that gonocyte numbers would be normal in $h p g$ testes. After birth, gonocytes in both normal and hpg testes re-entered mitosis but from a measure of the number of germ cells present on day 5 it is clear that the rate of proliferation is slower in the absence of circulating gonadotrophins. This may be a reflection of the lower rate of Sertoli cell proliferation at this time or a decrease in Sertoli cell activity through loss of FSH and testosterone stimulation (O'Shaughnessy et al., 1998).

This study was supported by awards from the BBSRC and the Wellcome Trust. The authors would like to thank W. V. Holt for assistance in recognition of germ cell morphology.

\section{References}

Ariyaratne HB, Mendis-Handagama SM, Hales DB and Mason JI (2000) Studies of the onset of Leydig precursor cell differentiation in the prepubertal rat testis Biology of Reproduction 63 165-171

Atanassova N, McKinnell C, Walker M, Turner KJ, Fisher JS, Morley M, Millar MR, Groome NP and Sharpe RM (1999) Permanent effects of neonatal estrogen exposure in rats on reproductive hormone levels, Sertoli cell number, and the efficiency of spermatogenesis in adulthood Endocrinology 140 5364-5373

Baker PJ, Sha JA, McBride MW, Peng L, Payne AH and O'Shaughnessy PJ (1999) Expression of $3 \beta$-hydroxysteroid dehydrogenase type I and VI isoforms in the mouse testis during development European Journal of Biochemistry 260 911-916

Behringer RR, Finegold MJ and Cate RL (1994) Mullerian-inhibiting substance function during mammalian sexual development Cell $\mathbf{7 9}$ 415-425

Bortolussi M, Zanchetta R, Belvedere P and Colombo L (1990) Sertoli and Leydig cell numbers and gonadotrophin receptors in rat testis from birth to puberty Cell and Tissue Research 260 185-191

Byskov A (1986) Differentiation of mammalian embryonic gonad Physiological Reviews 66 77-112

Cattanach BM, Iddon CA, Charlton HM, Chiappa SA and Fink G (1977) Gonadotrophin releasing hormone deficiency in a mutant mouse with hypogonadism Nature 269 338-340

Clark AM, Garland KK and Russell LD (2000) Desert hedgehog (Dhh) gene is required in the mouse testis for formation of adult-type Leydig cells and normal development of peritubular cells and seminiferous tubules Biology of Reproduction 63 1825-1838

Curtis SK and Amann RP (1981) Testicular development and establishment of spermatogenesis in Holstein bulls Journal of Animal Science $\mathbf{5 3}$ 1645-1657

Duckett RJ, Hedger MP, McLachlan RI and Wreford NG (1997) The effects of gonadotrophin-releasing hormone immunization and recombinant follicle-stimulating hormone on the Leydig cell and macrophage populations of the adult rat testis Journal of Andrology 18 417-423

Gondos B (1980) Development and differentiation of the testis and male reproductive tract. In Testicular Development, Structure and Function pp 3-20 Eds A Steinberger and B Steinberger. Raven Press, New York

Griswold MD (1993) Action of FSH on mammalian Sertoli cells. In The Sertoli cell pp 493-508 Eds LD Russell and MD Griswold. Cache River Press, Clearwater

Gundersen H (1986) Stereology of arbitrary particles Journal of Microscopy $1433-45$
Hardy MP, Zirkin BR and Ewing LL (1989) Kinetic studies on the development of the adult population of Leydig cells in testes of the pubertal rat Endocrinology 124 762-770

Hochereau-de Reviers MT, Perreau C, Pisselet C, Locatelli A and Bosc M (1995) Ontogenesis of somatic and germ cells in sheep fetal testis Journal of Reproduction and Fertility 103 41-46

Hu J, Shima H and Nakagawa H (1999) Glial cell line-derived neurotropic factor stimulates Sertoli cell proliferation in the early postnatal period of rat testis development Endocrinology 140 3416-3421

Johnson L, Zane RS, Petty CS and Neaves WB (1984) Quantification of the human Sertoli-cell population - its distribution, relation to germ-cell numbers, and age-related decline Biology of Reproduction 31 785-795

Jost A, Vigier B, Prepin J and Perchellet J (1973) Studies on sex differentiation in mammals Recent Progress in Hormone Research 29 $1-41$

Kluin PhM, Kramer MF and de Rooij DG (1984) Proliferation of spermatogonia and Sertoli cells in maturing mice Anatomy and Embryology 169 73-78

Lang J (1995) Assay for deletion in GnRH (hpg) locus using PCR Mouse Genetics 89 857-857

Lei ZM, Mishra S, Zou W, Xu B, Foltz M, Li X and Rao CV (2001) Targeted disruption of luteinizing hormone/human chorionic gonadotrophin receptor gene Molecular Endocrinology 15 184-200

Lejeune H, Habert R and Saez JM (1998) Origin, proliferation and differentiation of Leydig cells Journal of Molecular Endocrinology $\mathbf{2 0}$ $1-25$

Levine E, Cupp AS, Miyashiro L and Skinner MK (2000) Role of transforming growth factor-alpha and the epidermal growth factor receptor in embryonic rat testis development Biology of Reproduction 62 477-490

McLaren A (1984) Meiosis and differentiation of mouse germ cells. In Controlling Events in Meiosis pp 7-23 Eds CW Evans and HG Dickinson. Company of Biologists, Cambridge

Magre S and Jost A (1991) Sertoli cells and testicular differentiation in the rat fetus Journal of Electron Microscopy 19 172-188

Mayhew TM (1992) A review of recent advances in stereology for quantifying neural structure Journal of Neurocytology 21 313-328

Meachem SJ, McLachlan RI, de Kretser DM, Robertson DM and Wreford NG (1996) Neonatal exposure of rats to recombinant follicle stimulating hormone increases adult Sertoli and spermatogenic cell numbers Biology of Reproduction 54 36-44

Mendis-Handagama SMLC, Ariyaratne HBS, Teunissen van Manen KR and Haupt RL (1998) Differentiation of adult Leydig cells in the neonatal rat testis is arrested by hypothyroidism Biology of Reproduction 59 351-357

Nef S, Shipman T and Parada LF (2000) A molecular basis for estrogeninduced cryptorchidism Developmental Biology 224 354-361

Orth JM (1982) Proliferation of Sertolic cells in fetal and post-natal rats: a quantitative autoradiographic study Anatomical Record 203 485-492

Orth JM (1984) The role of follicle-stimulating hormone in controlling Sertoli cell proliferation in testes of fetal rats Endocrinology $\mathbf{1 1 5}$ 1248-1255

Orth JM, Gunsalus GL and Lamperti AA (1988) Evidence from Sertoli celldepleted rats indicates that spermatid number in adults depends on numbers of Sertoli cells produced during perinatal development Endocrinology 122 787-794

O'Shaughnessy PJ and Sheffield JW (1990) Effect of testosterone on testicular steroidogenesis in the hypogonadal ( $h p g$ ) mouse Journal of Steroid Biochemistry 35 729-734

O'Shaughnessy PJ, Baker P, Sohnius U, Haavisto A-M, Charlton HM and Huhtaniemi I (1998) Fetal development of Leydig cell activity in the mouse is independent of pituitary gonadotroph function Endocrinology $1391141-1146$

Petersen C, Froysa B, Boitani C and Soder O (2000) Transforming growth factor-alpha stimulates Sertoli cell proliferation in vitro. Andrologia 32 $62-63$

Racine C, Rey R, Forest MG, Louis F, Ferre A, Huhtaniemi I, Josso N and di Clemente N (1998) Receptors for anti-mullerian hormone on Leydig cells are responsible for its effects on steroidogenesis and cell differentiation Proceedings National Academy of Sciences USA 95 594-599 
Schmahl J, Eicher EM, Washburn LL and Capel B (2000) Sry induces cell proliferation in the mouse gonad Development 127 65-73

Scott IS, Charlton HM, Cox BS, Grocock CA, Sheffield JW and O'Shaughnessy PJ (1990) Effect of LH injections on testicular steroidogenesis, cholesterol side-chain cleavage P450 messenger RNA content and Leydig cell morphology in hypogonadal mice Journal of Endocrinology 125 131-131

Sharpe RM, Turner KJ, McKinnell C, Groome NP, Atanassova N, Millar MR, Buchanan DL and Cooke PS (1999) Inhibin B levels in plasma of the male rat from birth to adulthood: effect of experimental manipulation of Sertoli cell number Journal of Andrology 20 94-101

Sharpe RM, Walker M, Millar MR, Atanassova N, Morris K, McKinnell C, Saunders PT and Fraser HM (2000) Effect of neonatal gonadotropinreleasing hormone antagonist administration on Sertoli cell number and testicular development in the marmoset: comparison with the rat Biology of Reproduction 62 1685-1693

Singh J and Handelsman DJ (1996) Neonatal administration of FSH increases Sertoli cell numbers and spermatogenesis in gonadotropindeficient ( $h p g$ ) mice Journal of Endocrinology 151 37-48

Slegtenhorst-Eegdeman KE, de Rooij DG, Verhoef-Post M, van de Kant HJ, Bakker CE, Oostra BA, Grootegoed JA and Themmen AP (1998) Macroorchidism in FMR1 knockout mice is caused by increased Sertoli cell proliferation during testicular development Endocrinology 139 156-162

Steinberger A and Steinberger E (1971) Replication pattern of Sertoli cells in maturing rat testis in vivo and in organ culture Biology of Reproduction 4 84-87

Sterio D (1984) The unbiased estimation of number and sizes of arbitrary particles using the disector Journal of Microscopy 134 127-136

Teerds KJ, de Rooij DG, de Jong FH and van Haaster LH (1998) Development of the adult-type Leydig cell population in the rat is affected by neonatal thyroid hormone levels Biology of Reproduction $\mathbf{5 9}$ $344-350$

Thomas GB, McNeilly AS, Gibson F and Brooks AN (1994) Effects of pituitary-gonadal suppression with a gonadotrophin-releasing hormone agonist on fetal gonadotrophin secretion, fetal gonadal development and maternal steroid secretion in the sheep Journal of Endocrinology $141317-324$
Vainio S, Heikkila M, Kispert A, Chin N and McMahon AP (1999) Female development in mammals is regulated by Wnt-4 signalling Nature 397 405-409

van den Dungen HM, van Dieten JA, van Rees GP and Schoemaker J (1990) Testicular weight, tubular diameter and number of Sertoli cells in rats are decreased after early prepubertal administration of an LHRH-antagonist; the quality of spermatozoa is not impaired Life Sciences 46 1081-1089

van Haaster LH, de Jong FH, Docter R and de Rooij DG (1992) The effect of hypothyroidism on Sertoli cell proliferation and differentiation and hormone levels during testicular development in the rat Endocrinology 131 1574-1576

van Haaster LH, de Jong FH, Docter R and de Rooij DG (1993) High neonatal triiodothyronine levels reduce the period of Sertoli cell proliferation and accelerate tubular lumen formation in the rat testis, and increase serum inhibin levels Endocrinology 133 755-760

Vergouwen RPFA, Jacobs SGPM, Huiskamp R, Davids JAG and de Rooij DG (1991) Proliferative activity of gonocytes, Sertoli cells and interstitial cells during testicular development in mice Journal of Reproduction and Fertility 93 233-243

Vergouwen RPFA, Huiskamp R, Bas RJ, Roepers-Gajadien HL, Davids JAG and de Rooij DG (1993) Postnatal development of testicular populations in mice Journal of Reproduction and Fertility 99 479-485

Wreford NG (1995) Theory and practice of stereological techniques applied to the estimation of cell number and nuclear volume of the testis Microscopic Research Techniques 32 423-436

Zhang F-P, Poutanen M, Wilbertz J and Huhtaniemi I (2001) Normal prenatal but arrested postnatal sexual development of luteinizing hormone receptor knockout (LuRKO) mice Molecular Endocrinology 15 177-183

Received 25 October 2000.

First decision 7 December 2000

Resubmitted 15 March 2001.

Accepted 30 April 2001. 